\title{
Challenges of Enzymes, Conidia and 6-Pentyl-alpha-pyrone Production from Solid-State-Fermentation of Agroindustrial Wastes Using Experimental Design and T. asperellum Strains
}

\author{
Rayhane Hamrouni ${ }^{1,2}$. Magalie Claeys-Bruno ${ }^{1}$. Josiane Molinet ${ }^{1}$. Ahmed Masmoudi ${ }^{2} \cdot$ Sevastianos Roussos $^{1}$. \\ Nathalie Dupuy ${ }^{1}$
}

\begin{abstract}
In a context of growing awareness regarding environmental protection, biomass valorization is gaining a lot of attention. The byproducts volumes generated by agro-industry are massive and, left to decay, can constitute environmental pollutions. Use of agro-industrial wastes and solid-state fermentation (SSF) technology offers advantages to produce value-added products such as antibiotics, pigments, aromas and enzymes of industrial interest like cellulases, chitinases, amylases, etc. Several studies have already demonstrated the advantages of SSF for the production of fungal metabolites, yet the optimal conditions for metabolites production strongly depend on the culture conditions and microbial strain utilized. Therefore, the aim of this study was to improve the conidia, lytic enzymes (cellulase, lipase and amylase), and antifungal-6-pentylalpha-pyrones (6-PP)—production by three Trichoderma asperellum strains cultivated using SSF. Designs of experiments have been achieved in order to identify influential factors on 6-PP, conidia and enzymes (cellulase, lipase, and amylase) production by the fungal culture. A significantly enzymes activities, conidiation and 6-PP production were observed on mix of substrates: vine shoots, potatoes flour, jatropha, olive pomace and olive oil on high carbon/nitrogen ratio 37 which was used by T. asperellum TV104 as a source of nutrients and also as a matrix.
\end{abstract}

\section{Graphic Abstract}
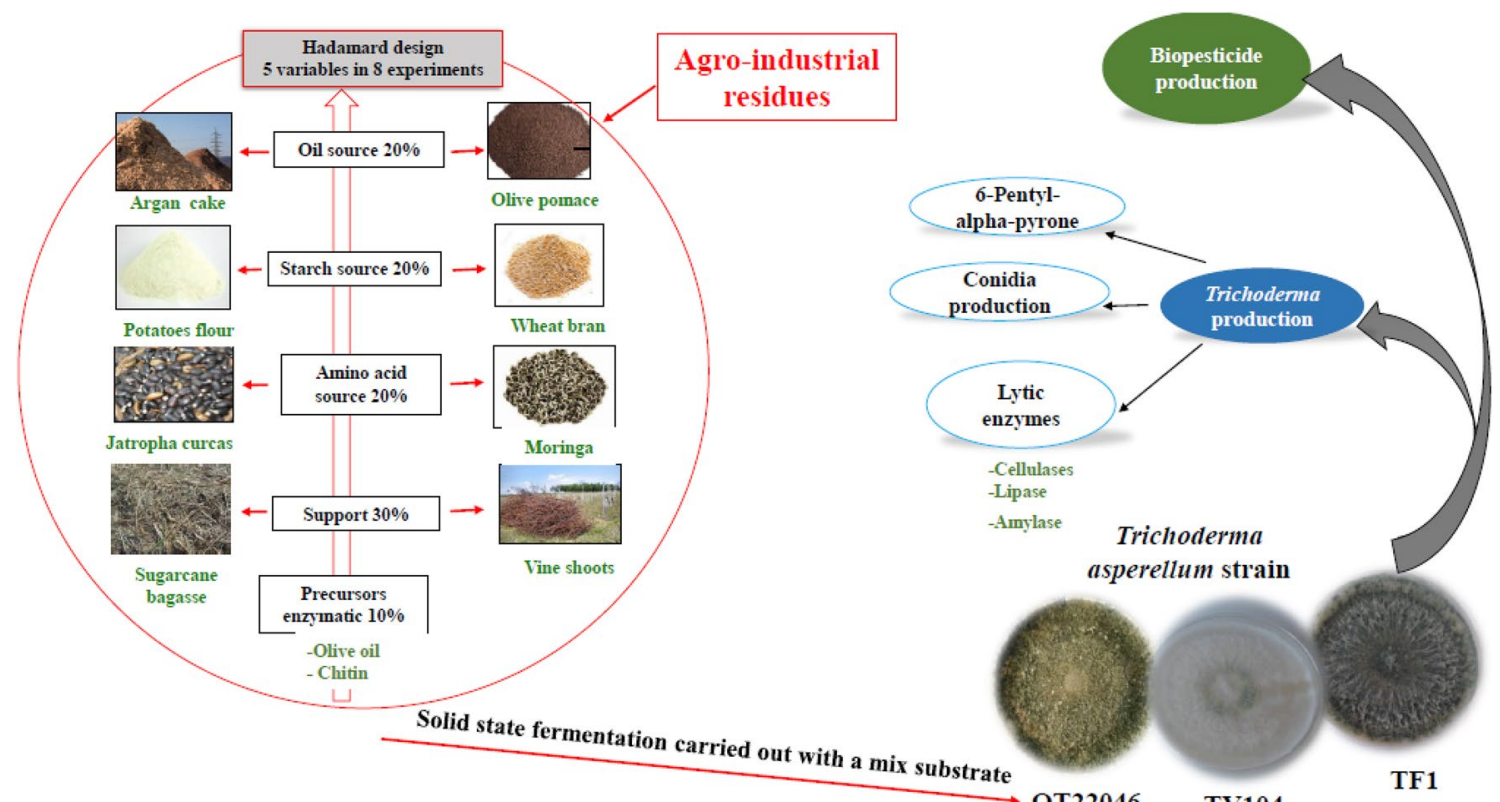

$\rightarrow$ QT22046

TV104 
Keywords Solid-state-fermentation $\cdot$ Trichoderma asperellum $\cdot$ Optimization $\cdot$ Agroindustrial wastes $\cdot$ Experimental design

\section{Statement of Novelty}

The development of sustainable solutions to exploit byproduct is necessary to solve the environmental problems. They are rich in nutrients can serve as a substrate for the production of interested compounds as antifungal ones. In this study various byproduct were valorized to formulate biopesticides by the way of solid state fermentation (SSF) and Trichoderma asperellum fungi. For the optimization of antifungal properties, Hadamard design was performed and various byproduct mixture. The final formulation allows to obtain high content in conidia, enzyme and 6-pentyl-alphapyrone (6-PP). This work presents two advantages: The valorization of agroindustrials wastes having an impact on the ecology of the world, and the production of interested compounds.

\section{Introduction}

Commonly agricultural produce important amount of byproducts whose main part are unused and cause environmental problems $[1,2]$. In recent years, numerous studies have been published supporting the use of SSF in valorization of agricultural byproducts in particular for microbial growth $[1,3]$. This technology has an economical interest according to agricultural byproducts (which are naturally rich in carbohydrates and other nutrients) as culture medium in SSF is cheaper than using synthetic substrates [3, 4]. Furthermore, one of the main driving forces in the increase of SSF popularity over the last decades is the growing concern about sustainability in bioprocess development linked to the possibility to use agro-industrial wastes having an impact on the worldwide ecology [5, 6]. Generally, SSF can be used for several applications such as enzyme production (pectinases, cellulases amylases, lipases) primary metabolites production (citric acid, lactic acid) secondary metabolites production (aromatic compounds, mycotoxins and organic volatile) and biomass production (mycelium, spores) [7, 8]. The most used agroindustrials wastes are: sorghum pulp, sugarcane bagasse, wheat, rice, corn, coconut fiber, coffee wastes, oil palm wastes, coconut oil mash, mustard oil mash, wheat flour [9].

In addition, there are several reports with the aim of filamentous fungi conidia production using sugarcane bagasse as support/substrate in SSF. Previously sugarcane bagasse is particularly suitable for SSF because of its porosity allowing good water absorption, indispensable to carried out the microbial metabolism [10]. Moreover, in term of volume, it is the major solid agro-industrial byproduct generated in Morocco, Brazil and Mexico [11]. Sugarcane bagasse is an inexpensive material rich in lignin (11\%) molecules, cellulose (38\%) and around 34\% of hemicelluloses components (Table 1) [11, 12]. Vine shoots is another agro-industrial

Table 1 Composition of different substrates tested

\begin{tabular}{|c|c|c|c|c|}
\hline Substrates & Origin & Characteristics, composition (g $100 \mathrm{~g}^{-1}$ dry matter) & $\begin{array}{l}\text { Carbon-nitro- } \\
\text { gen ratio } \\
(\mathrm{C} / \mathrm{N})\end{array}$ & Reference \\
\hline Argan press cake & Morocco & $\begin{array}{l}\text { Humidity (26.3\%), ashes (3.6), lipids (18.9), glucosides (26.6), cellulose } \\
\text { (17.6) }\end{array}$ & 7 & [45] \\
\hline Olive oil & France & $\begin{array}{l}\text { Fatty acids (\%): palmitic acid (13.6), cis vaccenic acid (2.45), oleic acid } \\
(68.1) \text {, linoleic acid (10.2), linolenic acid }(0.6)\end{array}$ & 94 & [46] \\
\hline Olive pomace & France & $\begin{array}{l}\text { Humidity (28\%), ashes (3.5), lignin (19.5), hemicellulose (16.8), cellulose } \\
\text { (11.5), lipid (7.2), protein (6.5) phenols (1.2) }\end{array}$ & 82 & [47] \\
\hline Jatropha cake & Burkina Faso & Humidity (4.1\%), protein (28.4), lipid (12), ashes (6.1) crude fiber (25.9) & 14 & [48] \\
\hline Moringa oleifera leaves & Burkina Faso & Humidity (75\%), protein (25.3), lipid (8.1), ash (5.2), crude fiber (15.3) & 10 & [49] \\
\hline Wheat bran & France & $\begin{array}{l}\text { Humidity (8.2), holocellulose (58.2), protein (13.8), lignin (5.7), lipid (7.4), } \\
\text { crude fibre (2.1), pectin (1.7), soluble sugars (1.4), ash (1.7) }\end{array}$ & 17 & {$[50]$} \\
\hline Potato flour & France & $\begin{array}{l}\text { Humidity (7.5), carbohydrate (75.2), protein (9.1), lipid (7.4), crude fibre } \\
\text { (2.1), ash (3.2) }\end{array}$ & 22 & [51] \\
\hline Vine shoots & France & $\begin{array}{l}\text { Humidity (10\%), cellulose (51.9), hemicellulose (22.3), lignin (16.6), lipids } \\
(0.5) \text {, tannins }(0.5) \text {, total nitrogen }(0.8) \text {, ashes }(2.5)\end{array}$ & 75 & {$[52]$} \\
\hline Sugarcane bagasse & Morocco & $\begin{array}{l}\text { Humidity (8\%), cellulose (41.6), hemicellulose (25.1), lignin (20.3), ashes } \\
\text { (4.8) }\end{array}$ & 151 & [53] \\
\hline Chitin & France & $\begin{array}{l}\text { Natural polysaccharide ( } \beta-(1-4)-N \text {-acetyl-D-glucosamine), the main com- } \\
\text { mercial sources of chitin are crab and shrimp shells }\end{array}$ & 20 & {$[54]$} \\
\hline
\end{tabular}


waste that recently attracted a lot of attention in fermentation process for filamentous fungi growth [13]. It is the most important byproduct in vine industry (France, Italy, Spain and Tunisia) generated during the pruning season. In this study, it will be used for the first time for Trichoderma metabolites production. Sugarcane bagasse and vine shoots will be compared as support of culture in the medium to possess favorable physical properties having consequence on water availability.

Moreover, the ideal substrate for filamentous fungi growth should offer several factors like mineral salts, starch, carbon, nitrogen, protein sources, etc. Those sources were proportioned with a mix of substrates. In 2017, the feasibility of wheat bran and potato flour as a substrate for SSF in order to produce Trichoderma harzianum conidias was demonstrated by De la Cruz-Quiroz et al. [14] showing that potato flour is a profitable starch source for the conidiation of Trichoderma. For this reason it is necessary to evaluate the effect of these substrates not only for conidia production but also for enzymes and secondary metabolites. On other hand, Tunisia, France, Italy, Spain and Morocco are the larger producers of olive oil. However, the processing of the high production of olive oil gives rise to a large amount of olive pomace (20 million tons) [15] which accumulation leads to an important problem of environmental pollution. For this reason, the opportunity to use this byproduct waste as the main oleaginous source in SSF is an important economic valorization approach, offering advantages in fermentation process.

Today, moringa and argan are the most commercial products for cosmetic sectors mainly in Africa especially in Cameroon, Burkina Faso, Morocco, and Tunisia [16, 17]. However, at the present time there is no published information about the treatment of the wastes generated during production process. Using moringa and argan cake as protein and lipid source in filamentous fungi growth seems to be a good idea. Generally natural sources (like amino acid) are preferably used than synthetic soluble compounds.

Based on the report published by International Fund for Agricultural Development (IFAD) Jatropha curcas represent an important waste generated by Africa country including; Mali, Burkina Faso, Senegal, Cameroon, followed by Asia and Latin America. This waste is toxic to human and environment but rich in protein which induce the production of lactones molecules [18]. Use of SSF and filamentous fungal strains may give an added value to jatropha cake, through bioconversions to produce value-added products such as antibiotics, pigments, lactone (with antifungal activity).

Globally, Trichoderma strains are the most important fungus used in SSF process. There are a great number of works reported the SSF process using Trichoderma strains for producing enzymes, conidia or secondary metabolites with industrial importance using different culture medium
$[6,19,20]$. However, it has not been reported the production of all these components at the same media in SSF by Trichoderma strains. In order to optimize fermentation media, statistically efficient tools as experimental designs [21-23] have been used to study the effects of several factors especially in the development of any fermentation process owing to their impact on the economy and to improve product yields. More precisely, screening strategies [24] are intended to identify very quickly active factors among many candidate factors with a few numbers of experiments. Indeed, at the beginning of a study, we generally do not know which factors have an influence on the studied responses. A screening of the factors will thus be performed to detect only the most important factors. This screening stage should involve a minimum number of experiments, and should not take much time of calculation. The most well-known screening designs are the Hadamard or Plackett and Burman design [25].

In this investigation, 6-PP, fungicidal secondary metabolite with coconut aroma, lytic enzymes (cellulase, amylase, lipase) and conidia producing strain of three T. asperellum, were subjected to optimization of media and cultivation parameters for metabolites production.

\section{Materials and Methods}

\section{Microorganisms and Culture Conditions}

The strains of T. asperellum TV104, T. asperellum TF1 and T. asperellum QT22046 from the IRD/IMBE fungi collection were used in present study. These strains were selected after a screening and identification of Trichoderma strains for 6-PP and conidia production (Hamrouni et al. [26]). The fungal strains were activated in sterilized potato dextrose agar (PDA) and incubated during 5 days at $30{ }^{\circ} \mathrm{C}$ to conserve at $4{ }^{\circ} \mathrm{C}$. Conidia obtained by culturing fungus in Erlenmeyer flasks containing PDA for $5-10$ days at $25^{\circ} \mathrm{C}$ were resuspended in $100 \mathrm{ml}$ sterile water solution containing Tween $80[0.01 \%(\mathrm{v} / \mathrm{v})]$ and quantified by using a traditional hemacytometer counting as described by Roussos et al. [27]. The amount of inoculum used in each fermentation was calculated to achieve an initial concentration of $2 \times 10^{7}$ conidia $\mathrm{g}^{-1} \mathrm{DM}$ (dry matter) used according to De la Cruz-Quiroz et al. [14].

\section{Solid-State Fermentation}

All the results being expressed in by gram of DM, the water content of each sample was measured as followed: after 5 days, $1 \mathrm{~g}$ of fermented material was introduced into a lab oven at $105{ }^{\circ} \mathrm{C}$ during $24 \mathrm{~h}$, to analyze the relative humidity of the sample [13]. 
SSF was performed in $250 \mathrm{ml}$ bottles containing $10 \mathrm{~g}$ of mixture substrates (DM). Each mixture was sieved to a 3-4 mm particle size. The humidity was set to $50 \%$ with distilled water before sterilization. All the culture media were then autoclaved at $121^{\circ} \mathrm{C}$ during $1 \mathrm{~h}$. Each mixture was then inoculated with $2 \times 10^{7}$ conidia $\mathrm{g}^{-1} \mathrm{DM}$, the volume of this added conidial suspension sets the initial humidity to $66 \%$. The cultures were performed in a laboratory incubator at $27{ }^{\circ} \mathrm{C} \pm 1{ }^{\circ} \mathrm{C}$ during 5 days (Fig. 1). Each condition has been performed in triplicate. The characteristics of the different substrate tested are shown in Table 1.

\section{The Carbon to Nitrogen (C/N) Ratio Analysis}

Total carbon $(\% \mathrm{C})$, total nitrogen $(\% \mathrm{~N})$ and $\mathrm{C} / \mathrm{N}$ ratio for all the substrates used and for the 8 medium tested were determined. Samples were firstly lyophilized (Lyophilizator Heto Power Dry LL 1500 Thermo Fischer Scientific, at $-109^{\circ} \mathrm{C}$ ) and then grounded in order to obtain a fine powder as homogenous as possible with a ball milling (MM 400 Retsch) $0.1 \mathrm{mg}$ of each broyat was used to analyse the $\% \mathrm{C}$, total $\% \mathrm{~N}$ and $\mathrm{C} / \mathrm{N}$ ratio with an elemental analyser Thermo Fisher Scientific (C) (USA).

\section{Conidia Determination}

Counting of conidia was done at the end of culture by mixing $1 \mathrm{~g}$ of fermented material and $100 \mathrm{ml}$ of sterile water containing Tween 80 [0.01\% (v/v)] in an Erlenmeyer flask, after that the suspension of conidia was counted using Malassez cell.

\section{Enzyme Assays}

Amylase activity was measured using soluble starch (1\%) in phosphate buffer $(0.1 \mathrm{M}, \mathrm{pH} 7.0)$ at $50{ }^{\circ} \mathrm{C}$ for $10 \mathrm{~min}$ [28]. Cellulase activity was determined using carboxymethyl cellulose $(1 \%)$ in sodium citrate buffer $(50 \mathrm{mM}, \mathrm{pH}$ 4.8 ) at $50{ }^{\circ} \mathrm{C}$ for $30 \mathrm{~min}$, in according with De la CruzQuiroz et al. [14]. An enzyme activity (U) was defined as the amount of enzyme that catalyzes the release of $1 \mu \mathrm{mol}$ of glucose $\min ^{-1}$. Lipase activity was determined using $0.5 \mathrm{ml}$ of $p$-nitrophenyl (25 mM) in phosphate buffer $(25 \mathrm{mM}, \mathrm{pH}$ $7.0)$ at $30{ }^{\circ} \mathrm{C}$ for $30 \mathrm{~min}[5,14]$. An enzyme activity (U) was defined as the amount of enzyme required to release $1 \mu$ mole of $p$-nitrophenol $\mathrm{min}^{-1}$.

\section{Extraction and Analysis of 6-PP}

6-PP was recovered by soxhlet extraction system from fermented material using pure heptane. Samples (10 $\mathrm{g}$ of the fermented material) were co-distilled at $60{ }^{\circ} \mathrm{C}$ with $100 \mathrm{ml}$ heptane during $45 \mathrm{~min}$. $1 \mathrm{ml}$ of a $\gamma$-undecanolactone solution
(80 $\mathrm{mg}^{-1}$ ) was added as the internal standard before extraction.

6-PP analysis were performed with a gas chromatograph 7890A (GC) (Agilent Technology) equipped with a split/ splitless injector $\left(\mathrm{T}=260{ }^{\circ} \mathrm{C}\right)$ and a flame ionization detector $\left(\mathrm{T}=260^{\circ} \mathrm{C}\right)$. Aroma constituents were separated on a Supelcowax capillary column (internal diameter $0.25 \mathrm{~mm}$, length $60 \mathrm{~m}$, film thickness $0.25 \mu \mathrm{m}$ ). The carrier gas was dihydrogen (column flow $1 \mathrm{ml} \mathrm{min}^{-1}$ ) and the split ratio was 1:2. The oven temperature was set as follows: $30 \mathrm{~min}$ at $180^{\circ} \mathrm{C}$, from 180 to $230{ }^{\circ} \mathrm{C}$ at $10^{\circ} \mathrm{C} \mathrm{min}^{-1}, 10 \mathrm{~min}$ at $230^{\circ} \mathrm{C}$.

Quantitative analysis of 6-PP was carried out using the internal calibration method, with $\gamma$-undecanolactone $(99 \%$, Aldrich) as internal standard.

\section{Experimental Design}

Screening study was performed to quantify the effects of five variables in eight experiments. Culture conditions; incubation temperature, moisture level, inoculum concentration and $\mathrm{pH}$, are fixed according to Sarhy-Bagnon et al. [29]. Responses variables were; 6-PP, conidia production and lytic enzymes (cellulase, lipase and amylase).

Factors and Domain of Interest The influences of five variables (support, starch source, protein source, oleaginous waste and precursors enzymatic) with two levels on the 6-PP, conidia, cellulases, lipases and amylases production were studied.

The same approach was employed for all the strains ( $T$. asperellum TV104, TF1 and QT22046). The experimental domain is shown in Table 2.

We can postulate that the result of each experiment is a linear combination of the effect of each five coded variables $\mathrm{X}_{1}, \mathrm{X}_{2}, \ldots, \mathrm{X}_{5}$. A first order polynomial model for the five variables with two levels is proposed.

$Y=b_{0}+b_{1} X_{1}+b_{2} X_{2}+b_{3} X_{3}+\cdots+b_{5} X_{5}+\varepsilon$.

In order to estimate the coefficients $b_{\mathrm{i}}$, a Hadamard design in eight experiments was performed (Table 3). It is valid only in the experimental points, and therefore cannot be used for any interpolation or extrapolation.

Repeatability in order to estimate the variability of each response, the experiment 6 has been triplicate. The generation and the data treatment of the designs were performed using the software Azurad.

\section{Results and Discussion}

The experiments of the Hadamard designs were done and the results are given in Table 4. 
Fig. 1 Representation of the SSF system

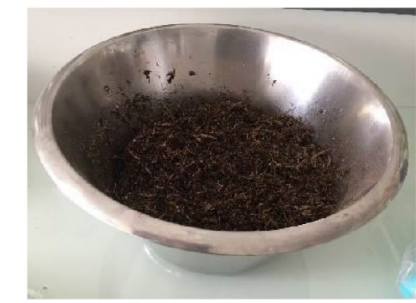

Sterilised Mixed substrates
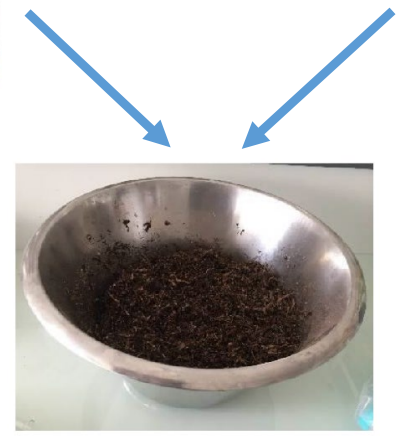

Inoculation

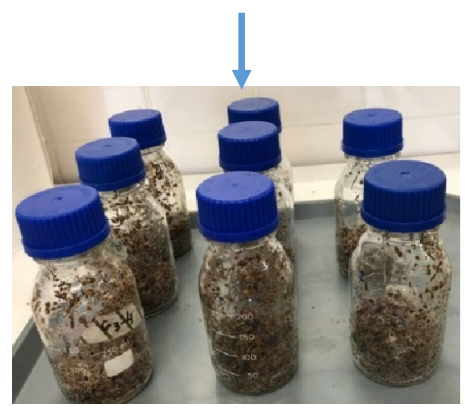

Distribution on Flasks bioreactor and incubation in a laboratory incubator at $27^{\circ} \mathrm{C} \pm$ $1^{\circ} \mathrm{C}$ during 5 days.

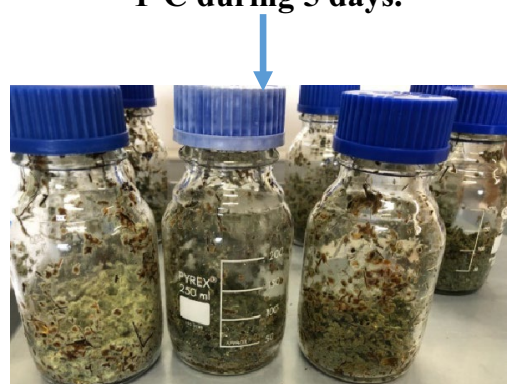

Growth of Trichoderma strains $\mathrm{SSC}$ at $27^{\circ} \mathrm{C}$.

(a)

$\downarrow$
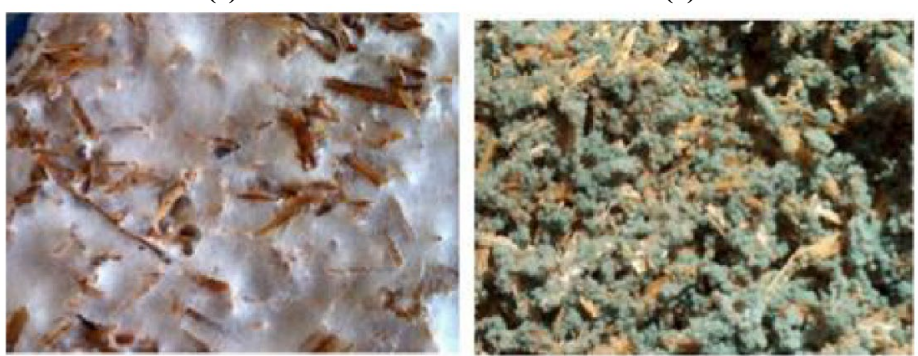

Aspect of fermented substrate after 2 days of culture (a) and 5 days (b) 
Table 2 Variables and levels

\begin{tabular}{lll}
\hline Variables & Level $(-)$ & Level $(+)$ \\
\hline $\mathrm{X}_{1}:$ support & Vine shoots & Sugarcane bagasse \\
$\mathrm{X}_{2}:$ starch source & Potatoes flour & Wheat bran \\
$\mathrm{X}_{3}:$ protein source & Jatropha cake & Moringa \\
$\mathrm{X}_{4}:$ oleaginous waste & Olive pomace & Argan cake \\
$\mathrm{X}_{5}:$ precursors enzymatic & Olive oil & Chitin \\
\hline
\end{tabular}

From the results, we can calculate the estimation of the model coefficients using multilinear regression. In order to check the significance of these coefficients, a student test has been performed.

\section{Effects Plot}

The coefficient values can be represented by an effect plot (Fig. 2) on which magnitudes and signs of each effect of the variables are shown. The red effects whether they are positive or negative, are the statistically significant ones. A significant limit (example Fig. 2a) could be calculated considering the variability calculated using triplicate which is represented by the vertical dotted line. Any coefficient exceeding this limit is considered active, which means that this variable is influential on the response. All coefficients not exceeding or near this limit are considered as inactive.

\section{Effect of Variables}

In order to choose the more favorable level of the variables, the value of the response for each level was calculated. The behaviour of each factor is presented in Fig. 3 (on the right), in orange the level (+) and in blue the level (-).

\section{Determination of the Solid Medium for T. asperellum TV104}

\section{*Conidia Production}

Figure 2 shows the effect, $b_{\mathrm{i}}$, of the tested variables. All the coefficients are significant. This mean that all the variables have a significant effect on the conidia production.

Thus, though it is a screening study, it can be observed that the presence of vine shoot, wheat bran, jatropha, olive pomace and chitin in the growth medium increases the conidia production by $T$. asperellum TV104. On the other hand, the presence of sugarcane bagasse, moringa, argan cake, olive oil and potatoes flour results in low conidia production.

\section{*Enzymes Activities}

Effects plots for cellulase, lipase and amylase activities are presented in the Fig. 3a Results of Hadamard design showed that cellulase activity by T. asperellum TV104 is more efficient when vine shoots, wheat bran, jatropha, olive pomace, and chitin are present in the medium. For lipase activity, the nature of the support and the starch source has scarcely significant effects, sugarcane bagasse and potatoes flour give a slightly higher activity than vine shoots and wheat bran. In opposite, protein source, oleaginous waste and enzymatic precursors are very influent variables. Jatropha, olive pomace and olive oil lead to high cellulase activity (Fig. 3b). For amylase activity, factors have no significant influence. Only the factor "oleaginous waste" seems to be important: olive pomace leads to higher activity.

6-PP Production Same statistical tools to identify significant effects on conidia or enzyme activities are used to study 6-PP production. Results obtained showed that all the tested

Table 3 Hadamard experimental design for the evaluation of relative importance of selected substrates for 6-PP, conidia production and enzymes activities produced by $T$. asperellum strains

\begin{tabular}{|c|c|c|c|c|c|}
\hline Experiments & Support $30 \%$ & Starch source $20 \%$ & Protein source $20 \%$ & Oleaginous waste $20 \%$ & $\begin{array}{l}\text { Enzymatic } \\
\text { precursors } \\
10 \%\end{array}$ \\
\hline 1 & Vine shoots & Potatoes flour & Jatropha cake & Olive pomace & Olive oil \\
\hline 2 & Sugarcane bagasse & Potatoes flour & Jatropha cake & Argan cake & Chitin \\
\hline 3 & Sugarcane bagasse & Wheat bran & Jatropha cake & Argan cake & Olive oil \\
\hline 4 & Vine shoots & Wheat bran & Moringa & Argan cake & Olive oil \\
\hline 5 & Sugarcane bagasse & Potatoes flour & Moringa & Olive pomace & Olive oil \\
\hline $6^{\prime}$ & Vine shoots & Wheat bran & Jatropha cake & Olive pomace & Chitin \\
\hline $6^{\prime \prime}$ & Vine shoots & Wheat bran & Jatropha cake & Olive pomace & Chitin \\
\hline $6^{\prime \prime \prime}$ & Vine shoots & Wheat bran & Jatropha cake & Olive pomace & Chitin \\
\hline 7 & Vine shoots & Potatoes flour & Moringa & Argan cake & Chitin \\
\hline 8 & Sugarcane bagasse & Wheat bran & Moringa & Olive pomace & Chitin \\
\hline
\end{tabular}




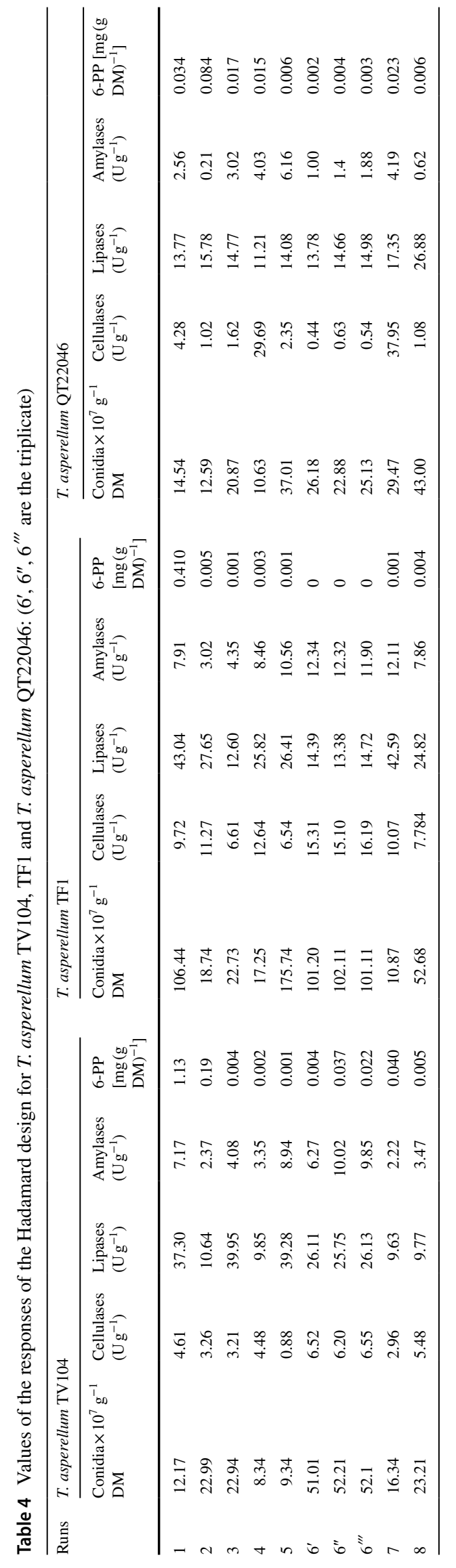

variables have a high effect on the 6-PP production. A mix of vine shoots, potatoes flour, jatropha, olive pomace and olive oil are the best conditions in the microbial production of 6-PP (Table 5).

\section{Determination of the Solid Medium for T. asperellum TF1 and T. asperellum QT22046}

Following the same idea, the optimal levels of the variables affecting the production of conidia, enzymes (cellulase, lipase, amylase) and 6-PP have been studied for T. asperellum TF1 and T. asperellum QT22046. The results of the Hadamard design experiments are presented in Table 4. Optimal conditions are given Table 5 for each response.

The mix of sugarcane bagasse, potatoes, moringa, olive pomace and chitin is the best conditions in the production of 6-PP, conidia, and enzymes activities by T. asperellum QT22046. For T. asperellum TF1 no significant effect of the entire variable tested on the 6-PP production were founded. Vine shoots have scarcely significant effects on the production of cellulase, lipase and amylase.

\section{Elemental Analysis of C/N Ratio}

The $\mathrm{C} / \mathrm{N}$ ratio is a marker to determine if the mixture substrates tested is a good candidate to fermentation process. Table 6 shows the $\mathrm{C} / \mathrm{N}$ ratio of the different solid medium tested. Among medium tested, the mixture containing 30\% of vine shoots, $20 \%$ of potatoes flour, $20 \%$ of jatropha, $20 \%$ of olive pomace and $10 \%$ of olive oil (medium 1) presents the optimal $\mathrm{C} / \mathrm{N}$ ratio (37). From these results, it is evident that $\mathrm{C} / \mathrm{N}$ ratio correlates with metabolites production because this mixture is the optimal medium defined for $T$. asperellum TV104 to produce 6-PP, conidia and enzymes.

\section{Discussion}

In SSF, cost and availability are the main factors considered to select suitable substrates for SSF [30]. In fact, wastes from the food and agricultural industries produced in large quantities and are rich in nutrients can serve as a substrate for the production of chemical compounds and enzymes by using the technique of SSF $[3,31]$.

Concerning culture media, substrates for SSF are usually homogeneous agro-industrial byproducts which offer advantages in this fermentation process. The culture medium has to be considered following two aspects: as substrate, it has to efficiently provide microbial nutritional needs, and as support of fungal culture, it has to possess favorable physical properties having consequence on water availability and allowing initial conidial anchorage, mycelial elongation in space and mass and heat transfers to occur over 
(a)

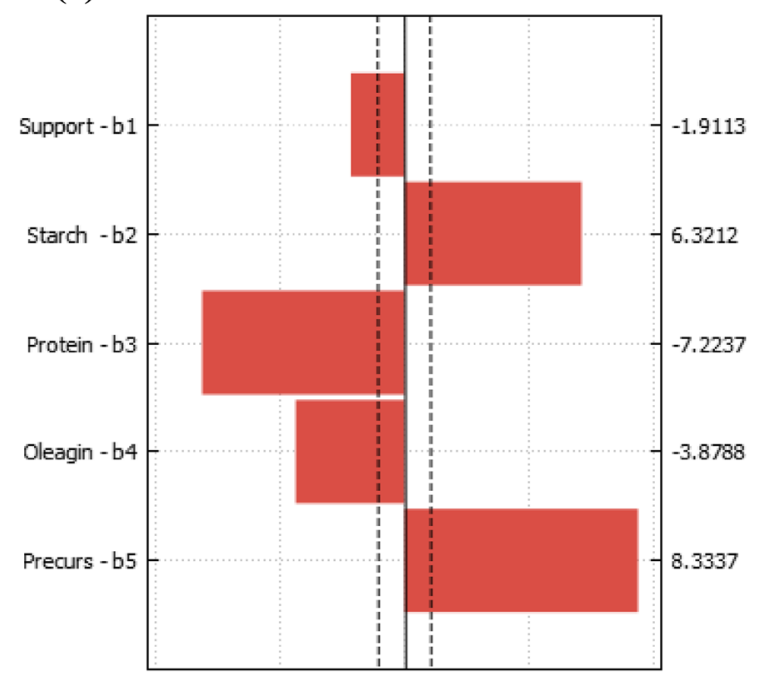

(b)

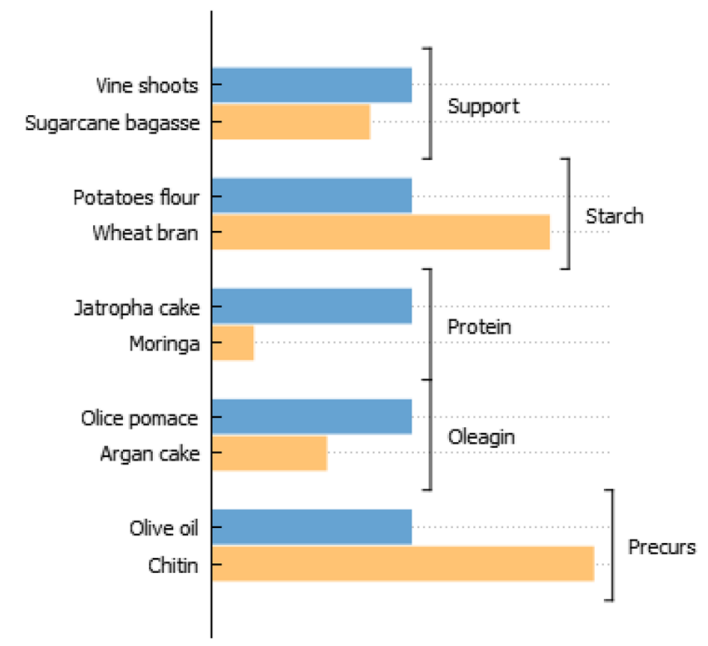

Fig. 2 Effects plot (a) and main levels effects (b) of the analysis for conidia production

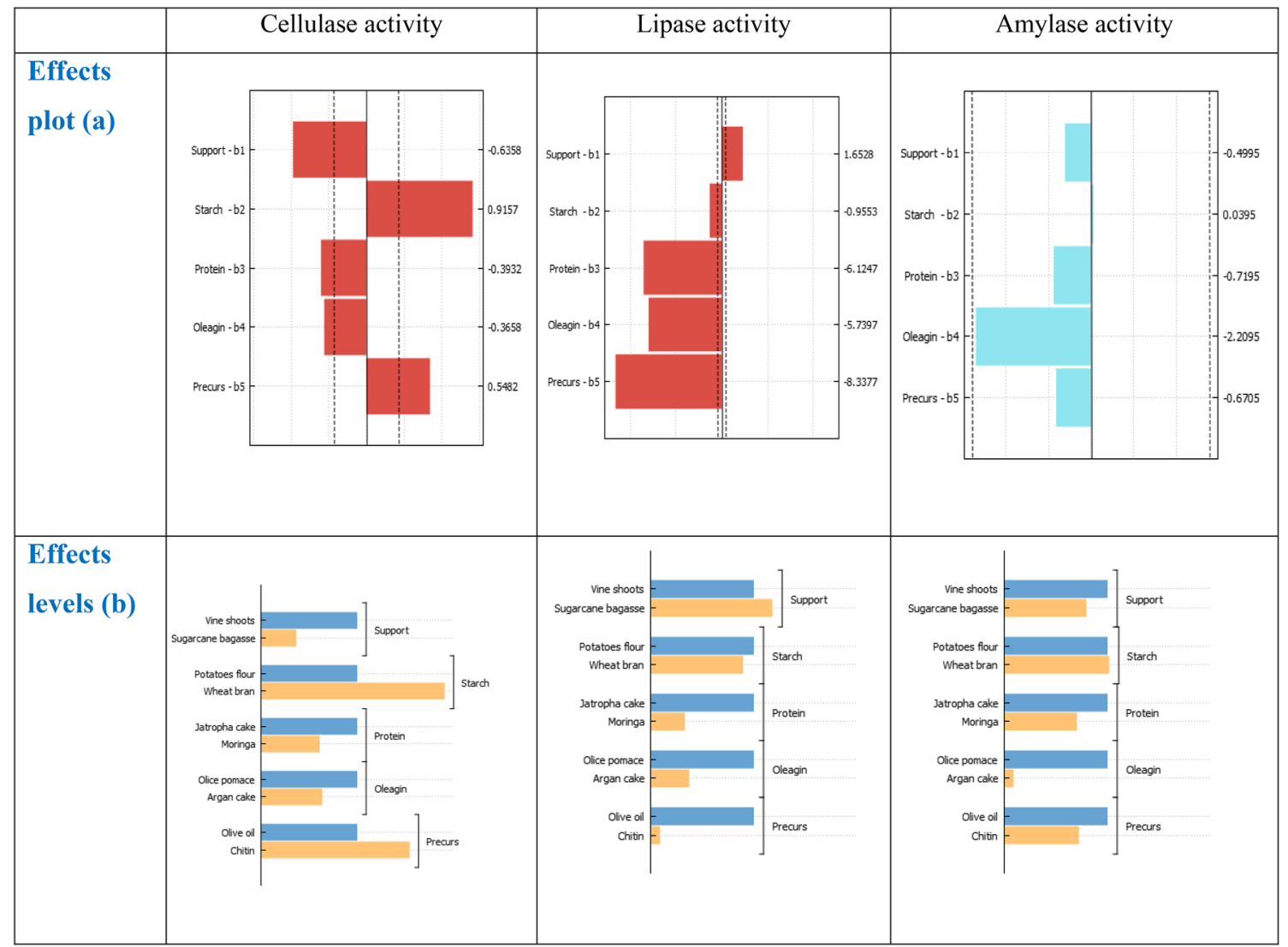

Fig. 3 Main levels effects of the analysis for cellulase, lipase and amylase activities from the Hadamard design for T. asperellum TV104

time $[9,11]$. Obviously, when using natural byproducts, the distinction between support and substrate may be blurry a solid substrate, because of its physical nature, participates as a support in the general texture of the culture medium.
However, in this case, a lignocellulosic byproduct as sugarcane bagasse or vine shoots rich in biopolymers is degraded, due to the production of some enzymes: the fungus preferentially consuming the more easily metabolizable compounds. 


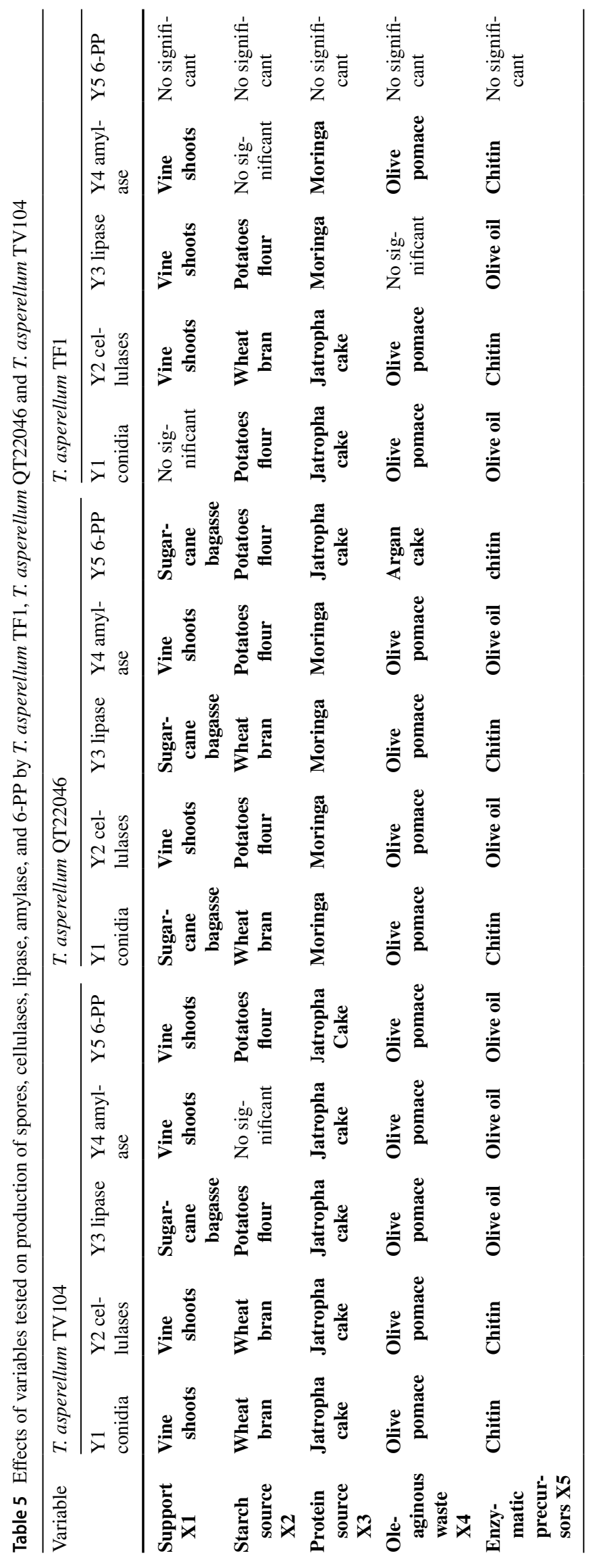


Table $6 \mathrm{C} / \mathrm{N}$ ratio of the eight solid medium tested

\begin{tabular}{ll}
\hline Experience & $\begin{array}{l}\text { The carbon- } \\
\text { nitrogen ratio } \\
(\mathrm{C} / \mathrm{N})\end{array}$ \\
\hline Medium 1 & 37 \\
Medium 2 & 14 \\
Medium 3 & 18 \\
Medium 4 & 16 \\
Medium 5 & 30 \\
Medium 6 & 20 \\
Medium 6 & 20 \\
Medium 6 & 20 \\
Medium 7 & 13 \\
Medium 8 & 24 \\
\hline
\end{tabular}

Following the same idea, substrates were selected, for their nutritional quality more than for their participation in the general texture of the medium. The vine shoot is considered as the best substrate for this SSF and for the secondary metabolites production, because it provides the necessary nutrients for physiology and fungi's growth, also constituting a good source of carbon and nitrogen (Table 1) [13, 32]. It is the first time that vine shoots have been used for the culture of $T$. asperellum strains to produce secondary metabolites. In addition, sugarcane bagasse was selected as substrate for further experimentation, not only because of its commercial potential as an agroindustrial byproduct and its suitability for enzymes, conidia and 6-PP formation but also because it has received much attention as a substrate for SSF [33-35]. For this reason, the opportunity for agroindustrial byproducts of low commercial value to be used as substrates in SSF is an important economic valorization, approach offering advantages in this fermentation process. Medium optimization is generally a time-consuming and labour-intensive process. The Hadamard design proved to be a valuable tool for the rapid evaluation of the effects of the various medium components with significant positive effects on the output. Since this design is a preliminary optimization technique, which tests only two levels of each variable, it cannot provide the optimal quantity of each factors required in the medium. However, this technique provides indications of how each component tends to affect the fungal conidiation and metabolites production. In this study a lower-cost medium to replace such medium described in literature to produce 6-PP, enzymes and conidia [20, 36-39] has been achieved.

Concerning substrate effects, enzymes activities, conidia and 6-PP production by T. asperellum TV104 are maximized with the presence of vine shoots, potatoes flour, jatropha cake, olive pomace, and olive oil. However, argan cake and moringa will be omitted because they decreased all the responses tested. Chitin and wheat bran will not be included in the medium because they inhibit 6-PP production and lipase activity. For T. asperellum QT22046, argan cake and jatropha cake have a positive effect on the production of 6-PP but they inhibit the production of conidia and enzymes activities. On the other hand, vine shoots and olive pomace maximize cellulases and amylase activities. The mixture of sugarcane bagasse, potatoes flour, moringa, olive pomace and chitin appears to be the adequate medium to maximize the production of all the responses by this strain.

On the other hand, it has been demonstrated a relationship between the high enzymes activities, conidia and 6-PP yields with the carbon nitrogen source supplied. Those sources were proportioned with a mix of substrates mentioned before, which contain amounts of nutrients like sugars, amino acids, lipid, fiber, and minerals. The balance of these nutrients may influence the 6-PP conidia production.

Comparing the $\mathrm{C} / \mathrm{N}$ ratio of the different medium tested, the maximum metabolites production by T. asperellum TV104 were achieved in $\mathrm{C} / \mathrm{N}$ ratio of 37 (medium 1) showing that Trichoderma strains use different carbon and nitrogen sources for metabolites production in SSF.

Considering that the mixture; vine shoots, potatoes flour, jatropha cake, olive pomace, olive oil are richer in protein, lipid and fatty acids, it appears that the biosynthesis of 6-PP are carried out from the metabolism of fatty acids which a common character of lactone production [14]. The cost of the new base medium is one-third of the cost of other medium indicated in literature on the production Trichoderma metabolites [11, 29, 40, 41]. For a broad application, the cost of chemical synthesis of 6-PP is one of the main factors limiting the process [29, 40, 42].

Reducing the costs of 6-PP production by optimizing the fermentation medium is the basic research for industrial application. However, using natural substrates as cultural medium, have some disadvantages, such as increasing the experimental variability leading to variations in the process performance, because of the complex nature of the substrate [43, 44]. In order to reduce the heterogeneity that may exist between two stocks of the same byproduct, it is recommended to use byproducts from the same industrial sector that preferentially have the same standardized pretreatments. Of course, the use of a single solid matrix impregnate with pure compounds may improve the repeatability of experiments; it is however possible to use a mixture of solid substrate and to have a good repeatability if the previous recommendations concerning the origin of the medium are respected.

\section{Conclusions}

In conclusion, it is important to note that a significant increment in the enzymes, conidia and 6-PP production by $T$. asperellum strains in SSF was achieved by modifying the 
culture conditions using an experimental design. The use of a Hadamard design allowed identification of the key variables that significantly affected the response tested. In addition, this strategy of optimizing the best medium leads inevitably to a maximized result. Significantly enzymes activities, conidiation and 6-PP production, were observed on the following mix of substrates: vine shoots, potatoes flour, jatropha cake, olive pomace and olive oil which was used by T. asperellum TV104 as a source of nutrients and also as a matrix.

The fact of using agricultural wastes as support or substrate for filamentous fungi growth and conidiation can produce value-added products of metabolites with reduced costs. Also, more variables could also be studied to fully optimize the fermentation process, such as for example, physical parameters like temperature, aeration, water stress and water activity which are of critical importance in SSF.

Acknowledgements Authors thank EURASMUS+ mobility for the financial support during the stay in France. R.H. also thank Tunisian Republic "Tunis El Manar University", the LR Biotechnology and Bio-Geo Resources Valorization (LR11ES31), the Higher Institute for Biotechnology "University of Manouba", the Institut Méditerranén de Biodiversité et d'Ecologie Marine et Continentale (IMBE), and the Planning Direction Office of Aix Marseille University for the support and technical facilities.

\section{References}

1. Couto, S.R., Sanromán, M.A.: Application of solid-state fermentation to food industry. J. Food Eng. 76, 291-302 (2006)

2. Nigam, P.S.: Production of bioactive secondary metabolites. In: Biotechnology for Agro-industrial Residues Utilisation. Springer, Dordrecht (2009)

3. Mascarin, G.M., Jaronski, S.T.: The production and uses of Beauveria bassiana as a microbial insecticide. World J. Microbiol. Biotechnol. 32(11), 177 (2016)

4. Thomas, L., Larroche, C., Pandey, A.: Current developments in solid-state fermentation. Biochem. Eng. J. 81, 146-161 (2013)

5. Mateos Diaz, J.C., Rodriguez, J.A., Roussos, S., Cordova, J., Abousalham, A., Carriere, F., Baratti, J.: Lipase from the thermotolerant fungus Rhizopus homothallicus is more thermostable when produced using solid state fermentation than liquid fermentation procedures. Enzyme Microb. Technol. 39, 1042-1050 (2006)

6. O'Callaghan, M.: Microbial inoculation of seed for improved crop performance: issues and opportunities. Appl. Microbiol. Biotechnol. 100, 5729-5746 (2016)

7. De la Cruz-Quiroz, R., Roussos, S., Hernandez-Castillo, D., Rodríguez-Herrera, R., López, L.I.L., Castillo, F., Aguilar, C.N.: Chapter 03: solid-state fermentation in a bag bioreactor: effect of corn cob mixed with phytopathogen biomass on spore and cellulase production by Trichoderma asperellum. In: Jozala, A.F. (ed.) Fermentation Processes. InTech, Rijeka (2017)

8. Carboué, Q., Perraud-Gaime, I., Tranier, M.S., Roussos, S.: Production of microbial enzymes by solid state fermentation for food applications. In: Ray, R.C., Rosell, C.M. (eds.) Microbial Enzyme Technology for Food Applications, pp. 437-451. CRC Press, Boca Raton (2017)
9. De la Cruz Quiroz, R., Roussos, S., Hernández, D., Rodríguez, R., Castillo, F., Aguilar, C.N.: Challenges and opportunities of the bio-pesticides production by solid-state fermentation: filamentous fungi as a model. Crit. Rev. Biotechnol. 35, 326-333 (2015)

10. Shi, Y., Xu, X., Zhu, Y.: Optimization of Verticillium lecanii spore production in solid-state fermentation on sugarcane bagasse. Appl. Microbiol. Biotechnol. 82, 921-927 (2009)

11. Fadel, H.H.M., Gomaa Mahmoud, M., Selim Asker, M.M., Nazeh Lotfy, S.: Characterization and evaluation of coconut aroma produced by Trichoderma viride EMCC-107 in solid state fermentation on sugarcane bagasse. Electron. J. Biotechnol. 18, 5-9 (2015)

12. Yong, F.M., Wong, H.A., Lim, G.: Effect of nitrogen source on aroma production by Trichoderma viride. Appl. Microbiol. Biotechnol. 22, 146-147 (1985)

13. Carboué, Q., Claeys-Bruno, M., Bombarda, I., Sergent, M., Jolain, J., Roussos, S.: Experimental design and solid state fermentation: a holistic approach to improve cultural medium for the production of fungal secondary metabolites. Chemom. Intell. Lab. Syst. 176, 101-107 (2018)

14. De la Cruz-Quiroz, R., Robledo-Padilla, F., Aguilar, C.N., Roussos, S.: Forced aeration influence on the production of spores by Trichoderma strains. Waste Biomass Valoriz. 8, 2263-2270 (2017)

15. Boubaker, F., Cheikh Ridha, B.: Anaerobic co-digestion of olive mill wastewater with olive mill solid waste in a tubular digester at mesophilic temperature. Bioresour. Technol. 98, 769-774 (2007)

16. Rébufa, C., Pany, I., Bombarda, I.: NIR spectroscopy for the quality control of Moringa oleifera (Lam.) leaf powders: prediction of minerals, protein and moisture contents. Food Chem. 261, 311-321 (2018)

17. Rueda, A., Seiquer, I., Olalla, M., Gimérez, R., Lara, L., CabreraVique, C.: Characterization of fatty acid profile of argan oil and other edible vegetable oils by gas chromatography. J. Chem. 8, 843-908 (2014)

18. Jingura, R.M., Kamusoko, R.: Experiences with Jatropha cultivation in sub-Saharan Africa: lessons for the next phase of development. Afr. J. Sci. Technol. Innov. Dev. 6, 333-337 (2014)

19. Pandey, A., Soccol, C.R., Mitchell, D.: New developments in solid state fermentation: I-bioprocesses and products. Process Biochem. 35, 1153-1169 (2000)

20. De Souza Ramos, A., Fiaux, S.B., Ferreira Leite, S.G.: Production of 6-pentyl- $\alpha$-pyrone by Trichoderma harzianum in solid-state fermentation. Braz. J. Microbiol. 39, 712-717 (2008)

21. Box, G.E.P., Hunter, W.G., Hunter, J.S.: Statistics for Experimenters, pp. 203-207. Wiley, New York (1978)

22. Droesbeke, J.J., Fine, J., Saporta, G.: Plans d'expériences, Applications à l'entreprise. Technip, Paris (1997)

23. Montgomery, D.C.: Design and Analysis of Experiments, 5th edn. Wiley, New York (2001)

24. Cela, R., Phan-Tan-Luu, R., Claeys-Bruno, M.: Screening strategies. In: Tauler, R., Walczak, B., Brown, S.D. (eds.) Comprehensive Chemometrics, pp. 251-300. Elsevier, Oxford (2009)

25. Plackett, R.L., Burman, J.P.: Design of optimal multifactorial experiments. Biometrika 23, 305-325 (1946)

26. Hamrouni, R., Molinet, J., Miché, L., Carboué, Q., Dupuy, N., Masmoudi, A., Roussos S.: Production of coconut aroma in solidstate cultivation: screening and identification of Trichoderma strains for 6-pentyl-alpha-pyrone and conidia production. J. Chem. ID 8562384 (2019)

27. Roussos, S., Olmos, A., Raimbault, M., Saucedo-Castañeda, G., Lonsane, B.K.: Strategies for large scale inoculum development for solid state fermentation system: conidiospores of Trichoderma harzianum. Biotechnol. Tech. 5, 415-420 (1991)

28. Singh, S., Singh, S., Bali, V., Sharma, L., Mangla, J.: Production of fungal amylases using cheap, readily available agriresidues, 
for potential application in textile industry. Biomed. Res. Int. 10, 1155-2158 (2014)

29. Sarhy-Bagnon, V., Lozano, P., Saucedo-Castañeda, G., Roussos, S.: Production of 6-pentyl-alpha-pyrone by Trichoderma harzianum liquid and solid state cultures. Process Biochem. 36, 103-109 (2000)

30. Demir, H., Tar1, C.: Valorization of wheat bran for the production of polygalacturonase in SSF of Aspergillus sojae. Ind. Crops Prod. 54, 302-309 (2014)

31. Soccol, C.R., Scopel Ferreira da Costa, E., Letti, L.A.J., Karp, S.G., Woiciechowski, A.L., de Souza Vandenberghe, L.P.: Recent developments and innovations in solid state fermentation. Microbiol. Res. J. 1, 52-71 (2017)

32. El Achaby, M., El Miri, N., Hannache, H., Gmouh, S., Ben Youcef, H., Aboulkas, A.: Production of cellulose nanocrystals from vine shoots and their use for the development of nanocomposite materials. Int. J. Biol. Macromol. 117, 592-600 (2018)

33. Sharma, A., Tewari, R., Rana, S.S., Soni, R., Soni, S.K.: Cellulases: classification, methods of determination and industrial applications. Appl. Biochem. Biotechnol. 179, 1346-1380 (2016)

34. Roussos, S., Lonsane, B.K., Raimbault, M., Viniegra Gonzalez, G.: Advances in Solid State Fermentation, p. 631. Kluwer Academic Publishers, Dordrecht (1997)

35. Stoykov, Y.M., Pavlov, A.I., Krastanov, A.I.: Chitinase biotechnology: production, purification, and application. Eng. Life Sci. 15, 30-38 (2015)

36. Maurya, D.P., Singh, D., Pratap, D., Maurya, J.P.: Optimization of solid state fermentation conditions for the production of cellulase by Trichoderma reesei. J. Environ. Biol. 33, 5-8 (2012)

37. Pham, T.A., Kim, J.J., Kim, K.: Optimization of solid-state fermentation for improved conidia production of Beauveria bassiana as a mycoinsecticide. Mycobiology 38, 129-137 (2010)

38. Sadaf, A., Khare, S.K.: Production of Sporotrichum thermophile xylanase by solid state fermentation utilizing deoiled Jatropha curcas seed cake and its application in xylooligosaccharide synthesis. Bioresour. Technol. 153, 126-130 (2014)

39. Galindo, E., Flores, C., Larralde-Corona, P., Corkidi-Blanco, G., Rocha-Valadez, J.A., Serrano-Carreon, L.: Production of 6-pentylalpha-pyrone by Trichoderma harzianum cultured in unbaffled and baffled shake flasks. Biochem. Eng. J. 18, 1-8 (2004)

40. Oda, S., Isshiki, K., Ohashi, S.: Production of 6-pentyl-a-pyrone with $T$. atroviride and its mutant a novel extractive liquid-surface immobilization (EXT-LSI) system. Process Biochem. 44, 625630 (2009)

41. Rocha-Valadez, A.J., Estrada, M., Galindo, E., Serrano-Carreon, L.: From shake flasks to stirred fermentors: scale-up of an extractive fermentation process for 6-pentyl-a-pyrone production by Trichoderma harzianum using volumetric power input. Process Biochem. 41, 1347-1352 (2016)

42. Onilude, A.A., Adebayo-Tayo, B.C., Odeniyi, A.O., Banjo, D., Garuba, E.O.: Comparative mycelial and spore yield by
Trichoderma viride in batch and fed-batch cultures. Ann. Microbiol. 63, 547-553 (2013)

43. Viniegra-González, G., Guevara-Gonzalez, R., Torres-Pacheco, I.: New horizons for the production of industrial enzymes by solidstate fermentation. In: Guevara-Gonzalez, R., Torres-Pacheco, I. (eds.) Biosystems Engineering: Biofactories for Food Production in the Century XXI, pp. 319-340. Springer, New York (2014)

44. Chen, L., Yang, X., Raza, W., Luo, J., Zhang, F., Shen, Q.: Solid state fermentation of agro-industrial wastes to produce bioorganic fertilizer for the biocontrol of Fusarium wilt of cucumber in continuously cropped soil. Bioresour. Technol. 102, 3900-3910 (2011)

45. Charrouf, Z., Guillaume, D.: Ethnoeconomical, ethnomedical, and phytochemical study of Argania spinosa (L.) Skeels. J. Ethnopharmacol. 67, 7-14 (2011)

46. Ollivier, D., Pinatel, C., Ollivier, V., Artaud, J.: Creation of a database of the fatty acid and triacylglycerol composition of virgin olive oils produced from 34 French varieties, eight French designations of origin and two foreign varieties grown in France (Part I). OLIVÆ 119, 35-47 (2014)

47. Medouni-Haroune, L., Zaidi, F., Medouni-Adrar, S., Kecha, M.: Olive pomace: from an olive mill waste to a resource, an overview of the new treatments. J. Crit. Rev. 5, 1-6 (2018)

48. Amsallem, I., Tréboux, M.: Jatropha cake: perspectives and constraints for valorization. Jatroref (2014). www.jatroref.org

49. Windépagnagdé Yaméogo, C., Daba Bengaly, M., Savadogo, A., Augustin Nikiema, P., Traore, S.A.: Determination of chemical composition and nutritional values of Moringa oleifera leaves. Pak. J. Nutr. 10, 264-268 (2011)

50. Sabry, S.A.: Protein-enrichment of wheat bran using Aspergillus terreus. Microbiologia 9, 125-133 (1993)

51. Avula, R.Y., Singh, R.K.: Functional Properties of Potato Flour and Its Role in Product Development: A Review. Food, Special Issue. Global Science Books, pp. 105-112 (2009)

52. Molina-Alcaide, E., Moumen, A., Martın-Garcia, A.I.: By-products from viticulture and the wine industry: potential as sources of nutrients for ruminants. J. Sci. Food Agric. 88, 597-604 (2008)

53. Kim, M., Day, D.F.: Composition of sugar cane, energy cane, and sweet sorghum suitable for ethanol production at Louisiana sugar mills. J. Ind. Microbiol. Biotechnol. 38, 803-807 (2011)

54. Song, Z., Li, G., Guan, F., Liu, W.: Application of chitin/chitosan and their derivatives in the papermaking industry. Polymers $\mathbf{1 0}$, 389 (2018)

\section{Rayhane Hamrouni $^{1,2}$. Magalie Claeys-Bruno ${ }^{1}$. Josiane Molinet ${ }^{1} \cdot$ Ahmed Masmoudi $^{2}$. Sevastianos Roussos ${ }^{1}$. Nathalie Dupuy ${ }^{1}$}

Rayhane Hamrouni

rayhan.hamrouni@gmail.com
2 Univ. Manouba, ISBST, BVBGR-LR11ES31, Biotechpole Sidi Thabet, 2020 Ariana, Tunisia

1 Aix Marseille Univ, Avignon Université, CNRS, IRD,

IMBE, Marseille, France 